\title{
Phytoextraction of Trace Metals (Cd, Ni and Pb) by Panicum maximum Grown on Natural Soil
}

\author{
Hogban Coulibaly ${ }^{1}$, Pétémanagnan Jean-Marie Ouattara ${ }^{1}$, Aman Messou $^{1 *}$, Lacina Coulibaly ${ }^{1,2}$ \\ ${ }^{1}$ Laboratory of Environment and Aquatic Biology, Department of Sciences and Environment Management, NANGUI \\ ABROGOUA University, Abidjan, Côte d'Ivoire \\ ${ }^{2}$ University of Man, Man, Côte d'Ivoire \\ Email: *messouaman@yahoo.fr
}

How to cite this paper: Coulibaly, H., Ouattara, P.J.-M., Messou, A. and Coulibaly, L. (2021) Phytoextraction of Trace Metals $(\mathrm{Cd}, \mathrm{Ni}$ and $\mathrm{Pb})$ by Panicum maximum Grown on Natural Soil. Open Journal of Applied Sciences, 11, 929-945.

https://doi.org/10.4236/ojapps.2021.118068

Received: June 4, 2021

Accepted: August 27, 2021

Published: August 30, 2021

Copyright $\odot 2021$ by author(s) and Scientific Research Publishing Inc. This work is licensed under the Creative Commons Attribution International License (CC BY 4.0).

http://creativecommons.org/licenses/by/4.0/

(c) (i) Open Access

\begin{abstract}
This study aims to assess the effective capacity of Panicum maximum to accumulate cadmium $(\mathrm{Cd})$, nickel $(\mathrm{Ni})$ and lead $(\mathrm{Pb})$. $P$. maximum observed in a greenhouse was subjected to $2 \mathrm{ppm}$ of $\mathrm{Cd}, 50 \mathrm{ppm}$ of $\mathrm{Ni}, 100 \mathrm{ppm}$ of $\mathrm{Pb}$ contaminated soil and uncontaminated soil, for 120 days. Plant growth and biomass produced concentration of trace metals in soil and plant, bioaccumulation and transfer factors, location of potentially toxic elements in tissues and cells of plant have been determined. Stem length and biomass produced by $P$. maximum were higher on the uncontaminated soil followed respectively by those of soil-contaminated by $\mathrm{Pb}, \mathrm{Cd}$ and $\mathrm{Ni}$. Bioaccumulation factors of trace metals were $8.93(\mathrm{~Pb}), 8.47(\mathrm{Ni})$ and $3.37(\mathrm{Cd})$. Ni was more accumulated in shoot biomass $(\mathrm{FT}>1)$, while $\mathrm{Pb}$ and $\mathrm{Cd}$ were concentrated in root biomass $(\mathrm{FT}<1) . \mathrm{Pb}$ is accumulated preferentially in endodermis (roots) and epidermis (leaves). As for $\mathrm{Ni}$ and $\mathrm{Cd}$, they are concentrated in central cylinder of roots and in conductive bundles of leaves. At cellular level, $\mathrm{Ni}$ and $\mathrm{Cd}$ are mainly concentrated in intracellular compartments of leaves and roots, while $\mathrm{Pb}$ is strongly detected at cell walls.
\end{abstract}

\section{Keywords}

Phytoextraction, Panicum maximum, Trace Metals, Bioaccumulation Factor, Transfer Factor

\section{Introduction}

Anthropogenic activities are the major source of many pollutants disseminated in the environment. Trace metals are among these priority risk pollutants because they are potentially very toxic and non-degradable elements. They stay in the environment for a long time [1]. These metals present in the soil cause risks 
to all the biosphere and are taken up through direct ingestion, absorbed by plants which can be hazardous both to the plant and also to the food chain [2] [3] [4]. At the microscopic scale, trace metals have adverse effects on bacterial populations, which are not without consequences on the functioning of the ecosystem [5]. Consequently, several physical and chemical remediation technologies for trace metals, contaminated soils have been developed. However, these technologies are generally expensive, greatly disrupt the biological activity of soils and alter their physical and chemical characteristics [6] [7]. As a result, research is increasingly directed towards biological processes exploiting the properties of living organisms (microorganisms or plants) to carry out the clean-up operation. In fact, despite their potential toxicity, most sites contaminated by trace metals often have a diverse flora that tolerates more or less high levels of metals. The study of these resistant plants, by their capacities of detoxification, immobilization or absorption of trace metals, paved the way for the development of a new tool for soil rehabilitation, phytoremediation [8]. Phytoremediation could provide a sustainable technique for metals-contaminated soils remediation. Indeed, phytoremediation is a less expensive technique, more extensive and ecological [9] [10] [11]. This technology has received more attention [12] and has shown better results in several countries [11] [13]. However, plant species previously experienced are not always present in Cote d'Ivoire. Consequently, their implementation may be confronted with problems of adaptation to local soils, hence the need to explore endogenous species with potential for accumulation. In Côte d'Ivoire, the work of Messou [14] on Akouédo landfill made it possible to assess the accumulation capacities of certain endogenous species, including Panicum maximum. This work has shown that this plant produced both a significant plant biomass and had a high potential for the accumulation of $\mathrm{Cd}, \mathrm{Pb}, \mathrm{Cu}, \mathrm{Ni}$ and $\mathrm{Zn}$ [14]. However, this study does not make it possible to apprehend the effects of competition or inhibition of trace metals. Moreover, the remediation mechanisms for trace metals were not elucidated. The work of Hogban et al. [15] carried out on synthetic soil also showed that Panicum maximum accumulates $\mathrm{Cd}, \mathrm{Ni}$ and $\mathrm{Pb}$. However, seen the interactions that could occur in natural soil, it has proven to be a good idea to replicate the work on natural soil. Thus, it involves evaluating the effect of the trace metals studied on the growth of plants and soil microorganisms, determining the potential for extraction of these trace metals by $P$. maximum and understanding their accumulation mechanisms.

\section{Material and Methods}

\subsection{Experimental Procedure}

The experimental was performed in a greenhouse (length $=13 \mathrm{~m}$ and width $=11$ $\mathrm{m}$ ) at the experimental site of the biotechnology and environmental engineering research unit of Nangui Abrogoua University, Côte d'Ivoire. It was equipped with a fan powered by a solar plate to regulate the temperature and the flow of 
air inside. Inside the greenhouse, 32 PVC pots (length $=27 \mathrm{~cm}$, width $=20 \mathrm{~cm}$, height $=45 \mathrm{~cm}$ ) containing soil contaminated or not, at a height of $40 \mathrm{~cm}$, were arranged.

\subsection{Soil}

Topsoil used was collected from an uncultivated plot of NanguiAbrogoua University. The soil was air dried, thoroughly mixed and sieved to $2 \mathrm{~mm}$. The soil was artificially contaminated with metallic salt. Depending on the desired contamination, the soils were saturated with an amount of metallic salt determined by Equation (1) [5] [16]:

$$
m_{\text {metallic salt }}=\frac{C \times m_{\text {soil }} \times M_{\text {metallic salt }}}{M_{\text {heavy metals }}}
$$

$m_{\text {metallic salt }}=$ mass of heavy metals $(\mathrm{mg})$;

$M_{\text {metallic salt }}=$ Molar mass of heavy metals $(\mathrm{g} / \mathrm{mol})$;

$M_{\text {heavy metal }}=$ Molar mass of heavy metals $(\mathrm{g} / \mathrm{mol})$;

$m_{\text {soil }}=$ Mass of soil in the pot $(\mathrm{kg})$;

$C=$ Theoretical concentration of heavy metals $(\mathrm{mg} / \mathrm{kg})$.

\subsection{Plant Selection}

Panicum maximum was selected according to its availability, its rapid growth and its potential tolerance of heavy metals $(\mathrm{Pb}, \mathrm{Cd}, \mathrm{Ni})$ [14]. In addition, $P$. maximum produces significant shoot and root biomass and has been described as phytoaccumulator [14] [17].

\subsection{Experimental Design}

The experiment was performed with plants grown on uncontaminated (control) and contaminated soil. Contaminated soil was treated with nickel (Ni), lead $(\mathrm{Pb})$, cadmium $(\mathrm{Cd})$. Each treatment was replicated eight times. Trace metals concentrations in soil at the start of experience were $2 \mathrm{ppm}$ for $\mathrm{Cd}, 50 \mathrm{ppm}$ for $\mathrm{Ni}$ and $100 \mathrm{ppm}$ for $\mathrm{Pb}$. Moreover, seedlings of $P$. maximum were used to establish nurseries on the experimental site. Plants with the same morphological development were selected and cultured.

\subsection{Data Collection}

Growth monitoring was carried out by weekly measurement of the height of the studied plant stems using a tape measure. Plants of two (2) replicates per trace metals contaminated were harvested monthly and the plant biomasses produced were determined by weighing on a $10^{-3}$ precision Sartorius EB150FEG-I scale.

Trace metals concentrations were analyzed on composite samples taken monthly from horizons (0 - 10, $10-20,20-30$ and $30-40 \mathrm{~cm})$ of soils. The samples were kept in hermetically sealed jars until analysis.

To assess trace metals accumulation, two (2) plant replicas were taken heavy metals contaminated soil every month (30 days). Harvested plants were sepa- 
rated into shoot and root parts. Each plant sample was washed with distilled water and high purity water. After air-drying, each plant sample was dried at $80^{\circ} \mathrm{C}$ to a constant weight. The dried samples were crushed using a stainless-steel plant tissue grinder (LD-Y500A).

\subsection{Samples Analysis}

Trace metals concentrations of soil were carried out according to the standard ISO 11466, [18]. The soil sample ( $0.5 \mathrm{~g})$ was digested with a mixture of $\mathrm{HCl}$ and $\mathrm{HNO}_{3}\left(7.5 \mathrm{ml}\right.$ of $\mathrm{HCl}$ and $2.5 \mathrm{ml}$ of $\left.\mathrm{HNO}_{3}\right)$. The content was filtered at $0.45 \mu \mathrm{m}$ and diluted up to $50 \mathrm{ml}$ with distilled water. Trace metals concentrations were determined by plasma-coupled induction atomic emission spectrometry (ICP-AES).

The mineralization of plant samples was made according to the standard NF X31-151 [19]. Subsample (20 g) of crushed plant material was oven-dried at $500^{\circ} \mathrm{C}$ for 2 hours and $0.5 \mathrm{~g}$ of that burned sample was digested with $10 \mathrm{ml}$ of aqua regia $\left(7.5 \mathrm{ml}\right.$ of $\mathrm{HCl}$ and $2.5 \mathrm{~mL}$ of $\left.\mathrm{HNO}_{3}\right)$. Then, the sample was put in an oven at $180^{\circ} \mathrm{C}$ for $30 \mathrm{~min}$ for ending digested process. The filtrate obtained after cooling was used for trace metals analysis by plasma coupled induction atomic emission spectrometry (ICP-AES).

\subsection{Phytoextraction Efficiency}

Two factors were calculated to evaluate plant phytoextraction efficiency. The bioaccumulation factor $(\mathrm{BF})$ was calculated to determine the degree of metal accumulation in the plants grown (Equation (2)) [20]. However the transfer factor (TF) defined as the ratio between the metal concentration in plant shoots and its concentration in roots (Equation (3)) [21] [22]. It indicated the capability of plants to take up trace metals from their roots and to translocate them to their shoots.

$$
\begin{gathered}
\mathrm{BF}=\frac{\text { Metal concentration in roots }+ \text { Metal concentration in shoots }}{\text { Metal concentration in soil }} \\
\mathrm{TF}=\frac{\text { Metal concentration in shoots }}{\text { Metal concentration in roots }}
\end{gathered}
$$

- TF $>1$ : accumulation of trace metals in the shoot biomass of plants;

- $\mathrm{TF}<1$ : accumulation of trace metals in the root biomass of plants.

\subsection{Localization of $\mathrm{Cd}, \mathrm{Ni}$ and $\mathrm{Pb}$ in Tissues and Cells of $P$. maximum}

This study determined the distribution of trace metals in plant roots and leaves, precisely at the tissue and the cell level. It was performed using a scanning electron microscope equipped with an X-ray detector connected to an EDS micro-analyzer platform (SEM-EDS). For the analyses, the plant materials (leaves and roots) were collected at the end of the experiment from the $\mathrm{Cd}, \mathrm{Ni}$ and $\mathrm{Pb}$ contaminated soil. Those samples were fixed for 24 hours in $2.5 \%$ glutaraldehyde ( $\mathrm{pH}$ 7.2). Then, they were rinsed two or more times with distilled water. A $2 \mathrm{~mm}$ cross-section of the samples (leaf or root) was followed by dehydration in suc- 
cessive baths of $30 \mathrm{~min}$ of ethanol (from 70\% - 100\%). The samples were subsequently dried in the open air and fixed on pads placed on a plate carried in the metallizer to spray them with gold. The plate was finally mounted on the stage of scanning electron microscope equipped with an X-ray detector connected to an EDS micro-analyzer platform to perform trace metals observations in the tissue and the cell.

\subsection{Statistical Analysis}

Statistical analysis of the data was performed with $\mathrm{R}$ software version 3.3.2. The normality of the data distribution of the variances was verified with the Shapiro test. To examine differences between growth and biomass produced by the plant in the culture pots, transfer factor and bioaccumulation factors, data were analyzed using the parametric test ( $\mathrm{t}$-test, ANOVA test) and the non-parametric test (Mann Whitney). Statistical significance was defined at the level of $\mathrm{p}<0.05$.

\section{Results}

\subsection{Plant Growth}

The growth of $P$. maximum, assessed from the average length of the stems during the treatment trial, is shown in Figure 1. Regular growth of the plant is observed the pots of culture. The order of the average lengths of stem at the end of the experiment is as follows: $176 \mathrm{~cm}\left(\mathrm{~S}_{\mathrm{Te}}\right)>167 \mathrm{~cm}\left(\mathrm{~S}_{\mathrm{Pb}}\right)>135 \mathrm{~cm}\left(\mathrm{~S}_{\mathrm{Cd}}\right)>83 \mathrm{~cm}$ $\left(\mathrm{S}_{\mathrm{Ni}}\right)$. Statistical analysis shows plant lengths of stem on Ni-contaminated soil is much smaller than those of the others (Mann-Whitney test: $\mathrm{p}<0.05$ ). On the other hand, growth of plant on uncontaminated soil (control soil) and that contaminated with $\mathrm{Pb}$ do not differ significantly (Mann-Whitney test: $\mathrm{p}>0.05$ ).

\subsection{Biomass Produced}

Figure 2 shows the variation of shoot and root biomass of $P$. maximum during the experiment. It noted that shoot and root biomasses increase over time.

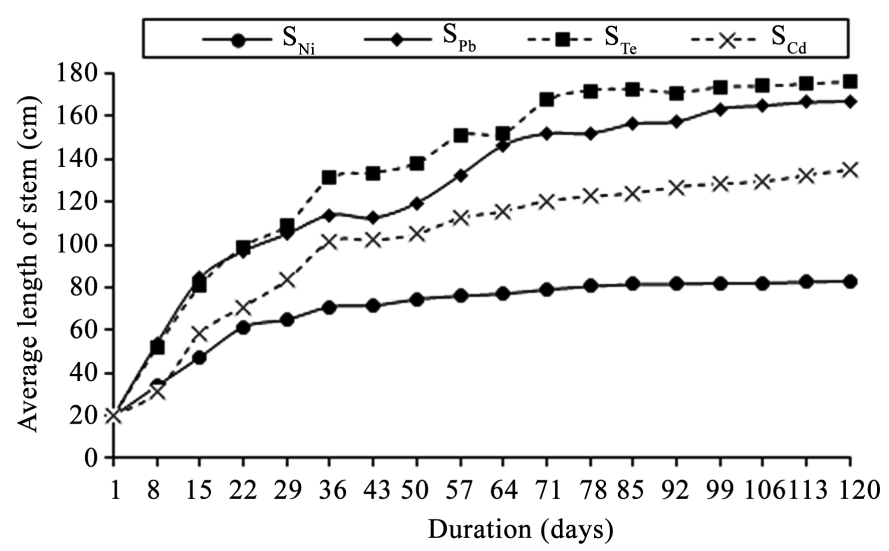

Figure 1. Growth profile of $P$. maximum stems during the experiment; $\mathrm{S}_{\mathrm{Te}}=$ Control soil soil; $\mathrm{S}_{\mathrm{Ni}}=$ Soil contaminated by nickel; $\mathrm{S}_{\mathrm{Cd}}=$ Soil contaminated bycadmium; $\mathrm{S}_{\mathrm{Pb}}=$ Soil contaminated by lead. 

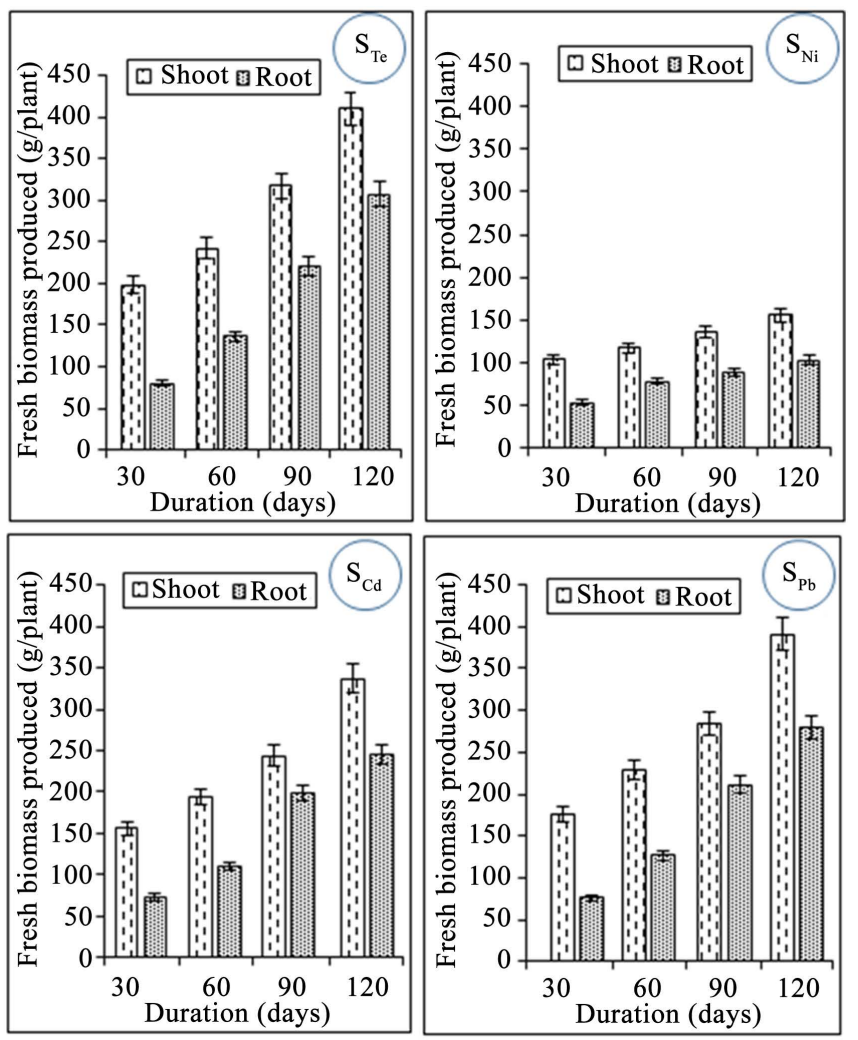

Figure 2. Plant biomass of $P$. maximum produced as a function of the duration of the treatment, $\mathrm{S}_{\mathrm{Te}}=$ Control soil; $\mathrm{S}_{\mathrm{Ni}}=$ Soil contaminated by nickel; $\mathrm{S}_{\mathrm{Cd}}=$ Soil contaminated by cadmium; $\mathrm{S}_{\mathrm{Pb}}=$ Soil contaminated by lead.

However, shoot biomass of $P$. maximum remains higher than the root biomass. From day 30 to day 120, shoot biomasses recorded vary from $198 \pm 1.8-409.5 \pm$ $5 \mathrm{~g}\left(\mathrm{~S}_{\mathrm{Te}}\right)$, de $176 \pm 32-390.3 \pm 4.3 \mathrm{~g}\left(\mathrm{~S}_{\mathrm{Pb}}\right)$, de $156 \pm 8.9-337 \pm 8.9 \mathrm{~g}\left(\mathrm{~S}_{\mathrm{Cd}}\right)$ et de $104 \pm 4.5-156.2 \pm 3 \mathrm{~g}\left(\mathrm{~S}_{\mathrm{Ni}}\right)$. On the other hand, root biomasses evolve from $80 \pm$ $1.5-306.4 \pm 5 \mathrm{~g}$, de $76.4 \pm 0.92-279.2 \pm 2.5 \mathrm{~g}$, de $72.6 \pm 0.4-244.8 \pm 1.5 \mathrm{~g}$ et de $53.8 \pm 1.6-103.5 \pm 2 \mathrm{~g}$, respectively in the uncontaminated soil (control soil) and those contaminated with $\mathrm{Pb}, \mathrm{Cd}$ and $\mathrm{Ni}$. Comparing biomasses (shoot and root) produced by $P$. maximum, we notice that biomass from Ni contaminated soil is much lower than others ( $\mathrm{t}$ test: $\mathrm{p}<0.05$ ) (Figure 3 ).

\subsection{Trace Metals Accumulation Potential of $P$. maximum}

$\mathrm{Pb}$ and $\mathrm{Cd}$ accumulation in the shoot and root biomasses of $P$. maximum (Table 1) indicated that the higher concentrations were recorded in the root. In contrast, Ni concentrations were higher in shoot biomass. However, concentrations of each trace metals obtained in shoot and root biomasses increase during treatment. $\mathrm{Pb}$ concentrations ranged from $23.93-234.7 \mathrm{ppm}$ in shoot biomass and from $36.62-384.75 \mathrm{ppm}$ in root biomass. For Cd, it ranged from $0.15-2.54$ ppm in shoot biomass and from $0.16-3.23 \mathrm{ppm}$ in root biomass. Ni concentrations in shoot and root biomass ranged from $33-216.75 \mathrm{ppm}$ and from 22.5 99.75 ppm, respectively. 

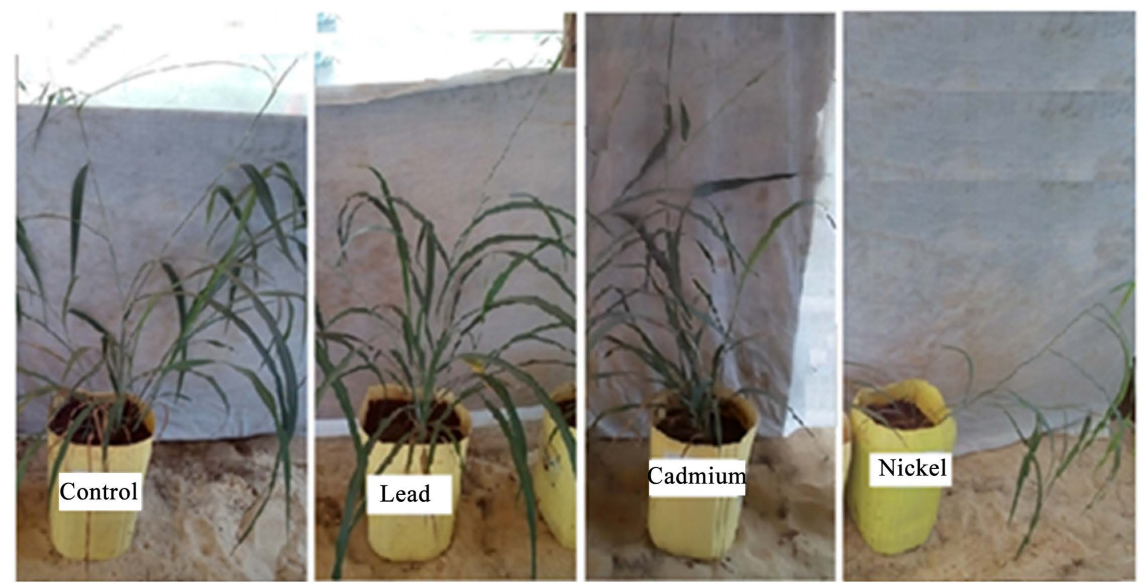

Figure 3. View of the plants at the end of the experiment.

Table 1. Concentration of trace metals in biomass of P. maximum.

\begin{tabular}{cccccc}
\hline & \multirow{2}{*}{ Trace metals (ppm) } & \multicolumn{4}{c}{ Time of experimentation (days) } \\
\cline { 3 - 6 } & & $\mathbf{3 0}$ & 60 & 90 & $\mathbf{1 2 0}$ \\
\hline \multirow{3}{*}{ Shoot } & $\mathrm{Ni}$ & 33 & 149.25 & 186 & 216.75 \\
& $\mathrm{~Pb}$ & 23.93 & 41.17 & 131.85 & 234.7 \\
& $\mathrm{Cd}$ & 0.15 & 0.74 & 2.04 & 2.54 \\
\hline \multirow{3}{*}{ Root } & $\mathrm{Ni}$ & 22.5 & 49.05 & 54.97 & 99.75 \\
& $\mathrm{~Pb}$ & 36.62 & 150 & 247.5 & 384.75 \\
& $\mathrm{Cd}$ & 0.16 & 0.92 & 2.4 & 3.23 \\
\hline
\end{tabular}

Table 2 shows the Bioaccumulation Factor (BF) and Transfer Factor (TF) of trace metals for $P$. maximum. BF values ranged from $0.64-8.93(\mathrm{~Pb}), 0.16-3.37$ $(\mathrm{Cd})$ and $1.2-8.47(\mathrm{Ni})$. These BF values were not significantly different (ANOVA test: $\mathrm{p}>0.05)$. Concerning TF values, they ranged from $0.41-0.91(\mathrm{~Pb})$, from $0.72-0.83(\mathrm{Cd})$ and from $1.47-3.38(\mathrm{Ni})$. The transfer factor for $\mathrm{Ni}$ was the highest and was greater than 1 . Moreover, TF for Ni were significantly different of $\mathrm{TF}$ for $\mathrm{Pb}$ and $\mathrm{Cd}($ ANOVA test: $\mathrm{p}<0.05$ ).

\subsection{Localization of $\mathrm{Cd}, \mathrm{Ni}$ and $\mathrm{Pb}$ in the Tissues and Cells of Panicum maximum}

Figures 4-6 show SEM/EDS of root and leaf of Panicum maximum accumulated trace metals $(\mathrm{Ni}, \mathrm{Pb}$ and $\mathrm{Cd})$. In tissues, $\mathrm{Pb}$ was accumulated preferentially on endodermis (roots) and epidermis (leaves). As for $\mathrm{Ni}$ and $\mathrm{Cd}$, they were concentrated in the central cylinder of roots and in the conductive bundles of leaves. Moreover, by carrying out the investigations at cellular level, it was noted that $\mathrm{Ni}$ and $\mathrm{Cd}$ were mainly concentrated in the intracellular compartments of leaves and roots of $P$. maximum, while $\mathrm{Pb}$ was strongly detected on the cell walls

\subsection{Density of Microorganisms in Soils}

Figure 7 shows the density of microorganisms (total mesophilic flora and 

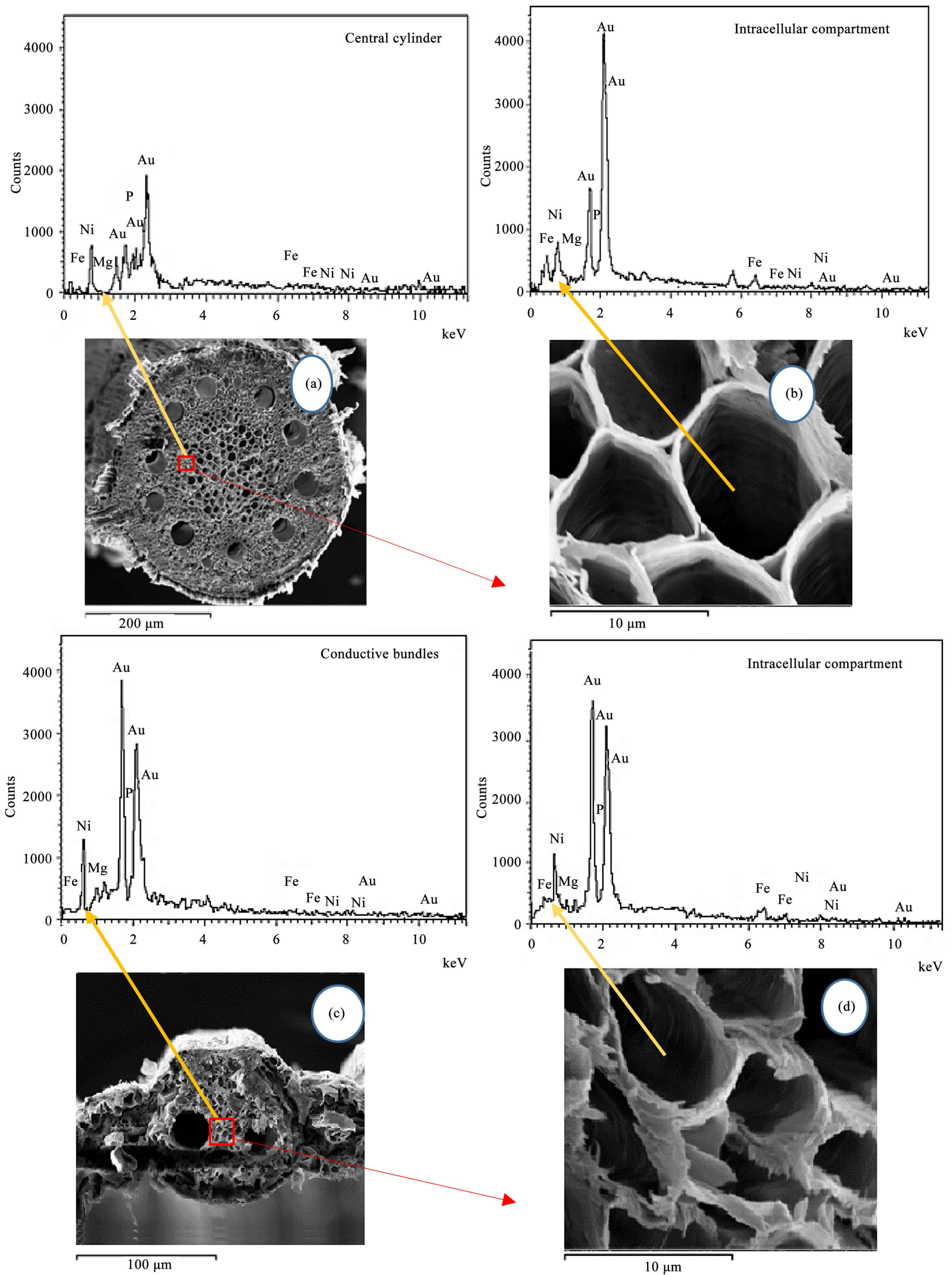

Figure 4. SEM/EDS of root ((a) and (b)) and leaf ((c) and (d)) of Panicum maximum accumulated Ni. 
H. Coulibaly et al.

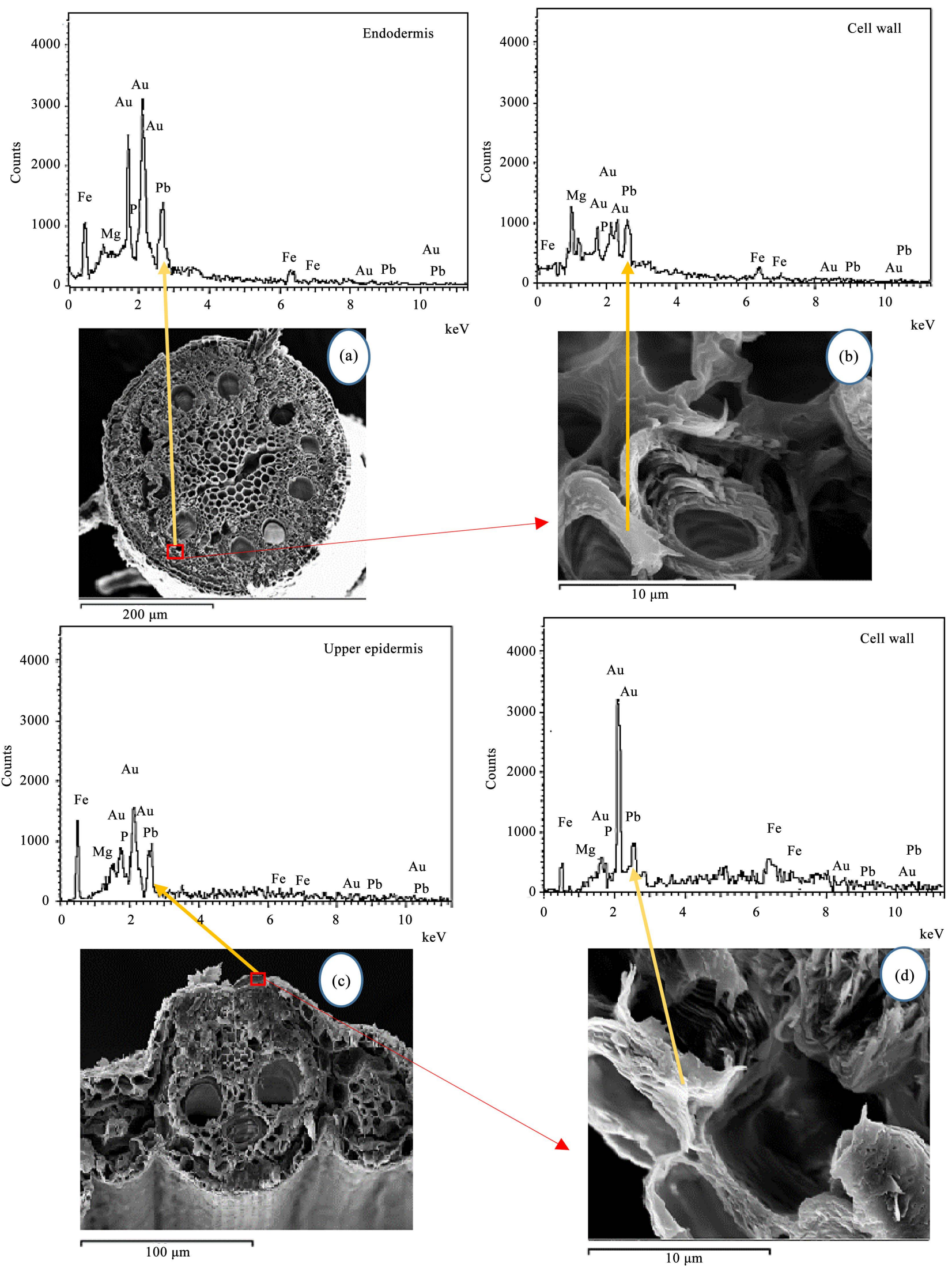

Figure 5. SEM/EDS of root ((a) and (b)) and leaf ((c) and (d)) of Panicum maximum accumulated $\mathrm{Pb}$. 

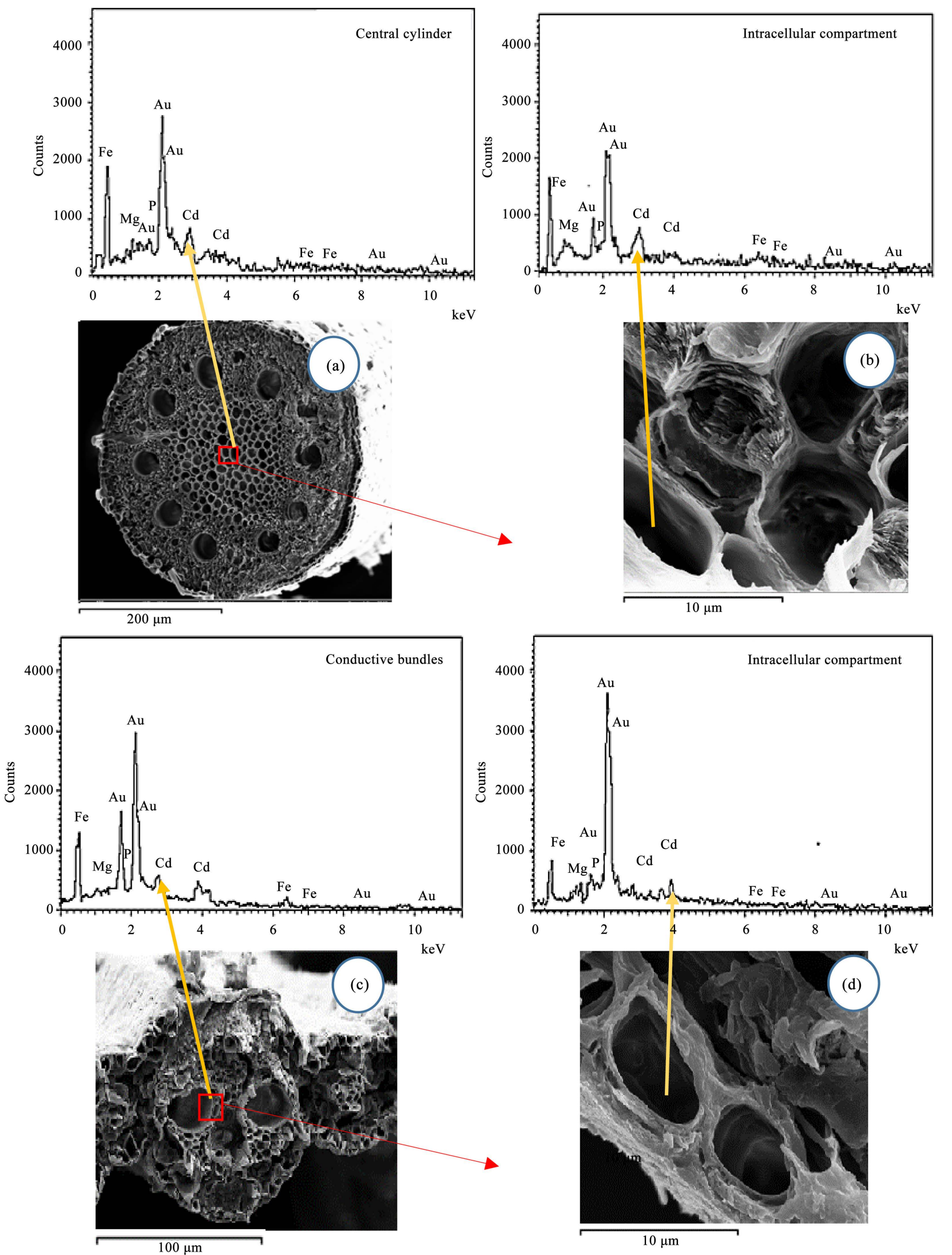

Figure 6. SEM/EDS of root ((a) and (b)) and leaf ((c) and (d)) of Panicum maximum accumulated Cd. 


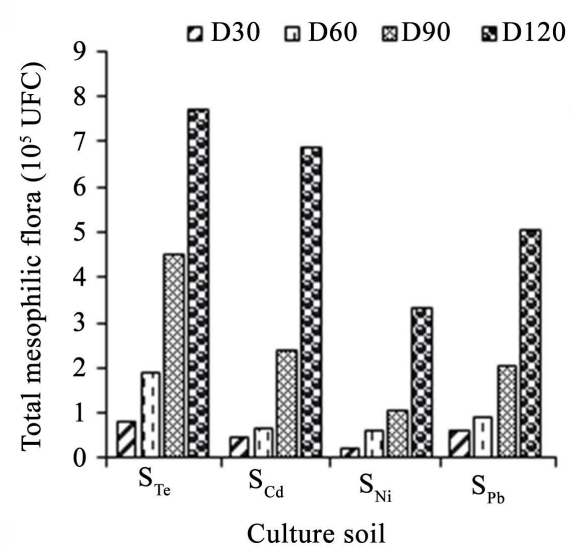

(a)

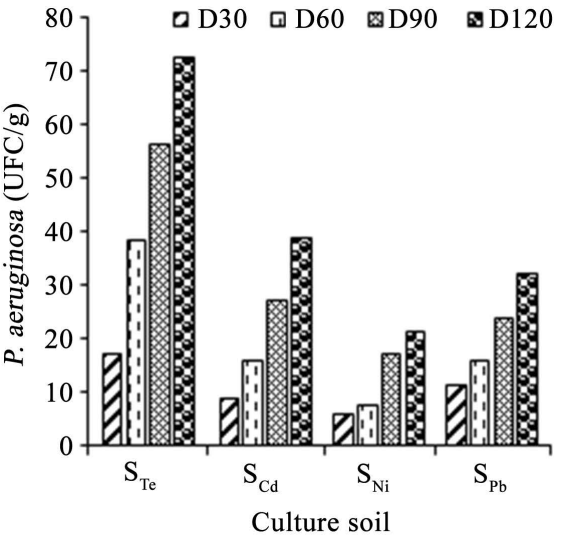

(b)

Figure 7. Density of microorganisms in soils; (a) total mesophilic flora and (b) P. aeruginosa; $\mathrm{S}_{\mathrm{Te}}=$ control soil; $\mathrm{S}_{\mathrm{Ni}}=$ soil contaminated by nickel; $\mathrm{S}_{\mathrm{Cd}}=$ soil contaminated by cadmium; $\mathrm{S}_{\mathrm{Pb}}=$ soil contaminated by lead.

Table 2. Bioaccumulation Factor (BF) and Transfer Factor (TF) of trace metals.

\begin{tabular}{cccccc}
\hline & & \multicolumn{4}{c}{ Time of experimentation (days) } \\
\cline { 3 - 6 } & & $\mathbf{3 0}$ & Day 60 & $\mathbf{3 0}$ & Day 120 \\
\hline \multirow{3}{*}{$\mathrm{BF}$} & $\mathrm{Ni}$ & 1.20 & 4.65 & 5.91 & 8.47 \\
& $\mathrm{~Pb}$ & 0.64 & 2.09 & 4.88 & 8.93 \\
& $\mathrm{Cd}$ & 0.16 & 0.90 & 2.50 & 3.37 \\
\hline \multirow{3}{*}{$\mathrm{TF}$} & $\mathrm{Ni}$ & 1.47 & 3.04 & 3.38 & 2.17 \\
& $\mathrm{~Pb}$ & 0.98 & 0.41 & 0.80 & 0.91 \\
& $\mathrm{Cd}$ & 0.83 & 0.72 & 0.77 & 0.71 \\
\hline
\end{tabular}

Pseudomonas aeruginosa) in the pots contaminated by $\mathrm{Pb}, \mathrm{Ni}$ and $\mathrm{Ni}$ and in control pot. It is observed that the density of microorganisms increases with duration of the treatment of the soils in the culture pots. In addition, densities recorded in the control remain the highest compared to those in contaminated pots. Densities of the total mesophilic flora ranged from $0.82 \times 10^{5}-7.72 \times 10^{5}$ $\mathrm{UFC} / \mathrm{g}$, from $0.48 \times 10^{5}-6.87 \times 10^{5} \mathrm{UFC} / \mathrm{g}$, from $0.24 \times 10^{5}-3.33 \times 10^{5} \mathrm{UFC} / \mathrm{g}$ and $0.62 \times 10^{5}-5.10 \times 10^{5} \mathrm{UFC} / \mathrm{g}$ respectively in control soil and $\mathrm{Cd}, \mathrm{Ni}$ and $\mathrm{Pb}$ contaminated soil, from day 30 to day 120 . These densities do not differ significantly (Kruskal-wallis test: $\mathrm{p}>0.05$ ). Concerning $P$. aeruginosa, its varies from $17.12-72.37 \mathrm{UFC} / \mathrm{g}$ in control, from $6-21.37 \mathrm{UFC} / \mathrm{g}$ in soil contaminated by $\mathrm{Ni}$, from $8.62-38.62 \mathrm{UFC} / \mathrm{g}$ in soil contaminated by Cd and from $11.25-31.87$ $\mathrm{UFC} / \mathrm{g}$ in soil contaminated by $\mathrm{Pb}$. Statistical analysis indicates that there is no significant difference between the densities of $P$. aeruginosa in the different soils culture (ANOVA test; $\mathrm{p}>0.05$ ).

\section{Discussion}

The present study aims to evaluate the capacity of Panicum maximum to accu- 
mulate trace metals $(\mathrm{Cd}, \mathrm{Ni}$ and $\mathrm{Pb})$ on natural soil. Plant growth appeared regular in both the contaminated and uncontaminated (control) soil, due to the considerable proportion of organic matter in the natural soil. However, a slowdown in plant growth has been observed in contaminated soil, possibly due to metal pollutants. Olatunji et al. [23] also observed such plant growth on soils contaminated by $\mathrm{Ni}, \mathrm{Pb}$ and $\mathrm{Cd}$. However, the analysis of the evolution of the plants revealed that the smallest sizes were recorded in soil contaminated by $\mathrm{Ni}$, probably related to the concentration in the biomass of $P$. maximum. Indeed this concentration of $\mathrm{Ni}$ is, according to Gerendás et al. [24], beyond the critical threshold $(10 \mathrm{ppm})$ of this trace metals in plant biomass. This result could be explained by the fact that $\mathrm{Ni}$ is an essential metal element for the plant, unlike $\mathrm{Cd}$ and $\mathrm{Pb}$, which are not essential. However, at high concentrations Ni affects plant growth [24]. This justifies much higher $P$. maximum sizes in $\mathrm{Pb}$ and $\mathrm{Cd}$ contaminated soil. However, bioaccumulation factors of $\mathrm{Pb}$ were higher, followed respectively by those of $\mathrm{Ni}$ and $\mathrm{Cd}$, indicating a high tolerance of $\mathrm{Pb}$ by $P$. maximum compared to others trace metals. This result is in agreement with those of several studies including Olatunji et al. [23], Olowoyo et al. [25] and Onojake and Enukoha [26] According to these authors, this sequence of accumulation of the trace metals studied is linked to the physiology of the plant, which tolerates more $\mathrm{Pb}$, compared to others metals. However, of all the trace metals, only the transfer factor of $\mathrm{Ni}$ is greater than 1, indicating a preferential accumulation of this metal in shoot biomass. These results are in agreement with those obtained in the treatment of synthetic soil [15] as well as those of the work of Messou [14. Several studies claim that once in the roots, $\mathrm{Ni}$ is preferentially translocated into the aerial parts of the plant [27] [28] [29]. Indeed, in the roots, according to Haydon and Cobbett [30] Montargès-Pelletier [31] and Araujo et al. [32] $\mathrm{Ni}$ binds to molecular organic ligands (citrate and malate) and amino acids (histidine, glutamine) to limit its precipitation. This complexation would be at the origin of the suppression of the sequestration of $\mathrm{Ni}$ in the root vacuoles and promote its transport to shoot of plants [33]. Regarding the soil microorganisms in the different growing soil, the results indicate that the density of total mesophilic flora and that of Pseudomonas aeruginosa increase during soil treatment. In fact, since these bacterial flora are aerobic organisms [34], the watering carried out during the trial would create ecological conditions favorable to a greater proliferation of these organisms. The flow of water through the growing soils would cause oxygen there, which is essential for the proliferation of bacteria during treatment [35] [36]. Furthermore, the increase in shoot biomass of the plant during the treatment would have promoted a similar growth of the root biomass, providing bacteria with more anchoring sites in the growing medium. This trend is similar to that observed in the work of Hogban et al. [15] on synthetic soils. However, the densities of total mesophilic flora and $P$. aeruginosa remain higher in natural soils compared to synthetic soils. The organic matter would be responsible for this situation. Indeed, because of the higher organic matter content, the soil would have favored a higher development of microor- 
ganisms in the culture pots [37]. SEM/EDS microanalysis performed in the root tissues of $P$. maximum shows that $\mathrm{Pb}$ preferentially accumulates in the cell walls of the endoderm. Patra et al. [38] and Seregin et al. [39] made these same observations. According to these authors, this property of $\mathrm{Pb}$ is also one of the reasons for its lower toxicity for the plant. In the leaves of $P$. maximum, $\mathrm{Pb}$ binds to the epidermis walls. This phenomenon is used as a strategy to prevent $\mathrm{Pb}$ from entering chloroplast cells were it can disrupt the $\mathrm{CO}_{2}$ binding system during photosynthesis [40]. As for $\mathrm{Ni}$ and $\mathrm{Cd}$, they are detected in quantity in the cells of the central cylinder of the roots. In contrast, in the leaves, these trace metals are concentrated in the conductive bundles. According to Chen et al. [41], Mendoza Cózatl et al. [42] and Gong et al. [43], Cd binds to ligands containing sulfhydril groups such as phytochelatins, glutathione and cysteines, mainly found in the xylem of the roots and the phloem of the leaves. Regarding to Ni, Chen et al. [41] indicate a high percentage (over $80 \%$ ) in the central cylinder of the roots. Thus, the great mobility of $\mathrm{Ni}$ in this tissue would have favored its translocation in shoots of the plant [44]. However, the significant accumulation of $\mathrm{Ni}$ in the conductive bundles of leaves affect the osmotic pressure of the cells of this tissue, especially the phloem responsible for transporting sugars throughout the plant [45].

\section{Conclusion}

The present study aims to determine the capacity of $P$. maximum to accumulate trace metals $(\mathrm{Pb}, \mathrm{Cd}, \mathrm{Ni})$ on natural soil. It appears that stem length and plant biomass produced by $P$. maximum was higher on the uncontaminated soil followed respectively by those of the soil contaminated by $\mathrm{Pb}, \mathrm{Cd}$ and $\mathrm{Ni}$. Bioaccumulation factors of trace metals were $8.93(\mathrm{~Pb}), 8.47(\mathrm{Ni})$ and $3.37(\mathrm{Cd}) . \mathrm{Ni}$ was more accumulated in shoot biomass $(\mathrm{FT}>1)$, while $\mathrm{Pb}$ and $\mathrm{Cd}$ were concentrated in root biomass $(\mathrm{FT}<1) . \mathrm{Pb}$ is accumulated preferentially in endodermis (roots) and epidermis (leaves). The densities of total mesophilic flora and Pseudomonas aeruginosa increased in all the pots. In tissues, lead is accumulated preferentially on endodermis (roots) and epidermis (leaves). As for Ni and Cd, they are concentrated in the central cylinder of roots and in the conductive bundles of leaves. Moreover, by carrying out the investigations at cellular level, it is noted that $\mathrm{Ni}$ and $\mathrm{Cd}$ are mainly concentrated in the intracellular compartments of leaves and roots of $P$. maximum, while $\mathrm{Pb}$ is strongly detected on the cell walls. If the results of the present study have shown the capacity of $P$. maximum to remediate soils contaminated with $\mathrm{Ni}, \mathrm{Pb}$ and $\mathrm{Cd}$. Studies should be conducted with increasing concentrations of $\mathrm{Ni}, \mathrm{Pb}$ and $\mathrm{Cd}$ to determine the maximum concentrations for which $P$. maximum can still keep its capacity for soil remediation.

\section{Acknowledgements}

We sincerely thank the members of the research team in Biotechnology and En- 
vironmental Engineering of Nangui Abrogoua University (Abidjan, Côte d'Ivoire) for their help during the field sampling, their critical examinations and their useful suggestions, all of which have greatly improved this manuscript

\section{Conflicts of Interest}

The author reported no potential conflict of interest.

\section{References}

[1] Redon, P.O. (2009) Role of Arbuscular Mycorrhizal Fungi in the Transfer of Cadmium (Cd) from Soil to Alfalfa (Medicagotruncatula). PhD Thesis, Henri Poincaré University of Nancy, Nancy.

[2] Nadzifah, Y, Muhammad, N.A.R., Muhamad, N.H., Aishatul, A.H. and Mazira, M. (2017) Determination of Cadmium and Zinc Concentration in Fish and Water from Sungai Kelantan. World Applied Sciences Journal, 35, 1808-1815.

[3] Merhaby, D., Ouddane, B., Net, S. and Halwani, J. (2018) Assessment of Trace Metals Contamination in Surficial Sediments along Lebanese Coastal Zone. Marine Pollution Bulletin, 133, 881-890. https://doi.org/10.1016/j.marpolbul.2018.06.031

[4] Diop, C, Diatta, A., Ndiaye, A., Cabral, M., Toure, A. and Fall, M. (2019) Teneurs en métaux traces des eaux et poissons de cinq étangs de Dakar et risques pour la santé humaine. Journal of Applied Biosciences, 137, 13931-13939.

https://doi.org/10.4314/jab.v137i1.1

[5] Huynh, T. (2009) Impact of Heavy Metals on Plant/Earthworm/Telluric Microflora Interaction. PhD Thesis, East Paris University, Paris.

[6] Alkorta, I. and Garbisu, C. (2001) Phytoremediation of Organic Contaminants in Soils. Bioresource Technology, 79, 273-276. https://doi.org/10.1016/S0960-8524(01)00016-5

[7] Lear, G., Harbottle, M.J., Sills, G., Knowles, C.J., Semple, K.T. and Thompson, P. (2007) Impact of Electrokinetic Remediation on Microbial Communities within PCP Contaminated Soil. Environmental Pollution, 146, 139-146. https://doi.org/10.1016/j.envpol.2006.06.037

[8] Nouri, M. and Haddioui, A.E.M. (2016) Assessment of Metals Contamination and Ecological Risk in Ait Ammar Abandoned Iron Mine Soil, Morocco. Ekologia, 35, 32-49. https://doi.org/10.1515/eko-2016-0003

[9] Verdin, A. (2004) Les agents de la bioremédiation des sols pollués par les hydrocarbures aromatiques polycycliques. Déchets sciences et techniques, No. 36, 30-37. https://doi.org/10.4267/dechets-sciences-techniques.2155

[10] Kirpichtchikova, T. (2010) Phytoremediation by Filter Gardens of Soil Polluted by Heavy Metals. Approaching Phytoremediation in Wetland Plants and Studying the Mechanisms of Remobilization/Immobilisation of Zinc and Copper. PhD Thesis, Joseph Fourier University, Grenoble.

[11] Origo, N., Stanislas, W. and Micheline, H. (2012) Rehabilitation of Sites Polluted by Phytoremediation. Natures and Metropolises. VertigO, 12, 1-4. https://doi.org/10.4000/vertigo.12633

[12] Belluck, D.A., Benjamin, S.L. and David, S. (2006) Why Remediate? In: Morel, J.-L., Echevarria, G. and Goncharova, N., Eds., Phytoremediation of Metal Contaminated Soils, Springer, Dordrecht, 1-23. https://doi.org/10.1007/1-4020-4688-X_1

[13] Maxted, A.P., Black, C.R., West, H.M., Crout, N.M.J., McGrath, S.P. and Young, 
S.O. (2007) Phytoextraction of Cadmium and Zinc from Arable Soils Amended with Sewage Sludge Using Thlaspic aerulescens. Development of a Predictive Mode! Environmental Pollution, 150, 363-372.

https://doi.org/10.1016/j.envpol.2007.01.021

[14] Messou, A. (2015) Characterization of Soil Pollution with Metallic Trace Elements and Evaluation of the Phytoaccumulation Capacities of Certain Endogenous Amaranthaceae and Poaceae Species from the Akouédo Landfill (Abidjan, Côte d'Ivoire). PhD Thesis, Nangui Abrogoua University, Abidjan.

[15] Hogban, C., Aman, M., Jean-Marie, P.O. and Lacina, C. (2020) Phytoextraction Capacity of Panicum maximum Grown on Synthetic Heavy Metals Contaminated Soil. Trends in Applied Sciences Research, 15, 281-292.

https://dx.doi.org/10.3923/tasr.2020.281.292

[16] Atma, W. (2016) Study of the Self-Purifying Power of Some Plants (Phytoremediation). PhD Thesis, University of Mascara, Mascara.

[17] Karangwa, E., Gordian, O. and Ochekwu, E.B. (2018) Phytoremediation Potentials of Guinea Grass (Panicum maximum) and Velvet Bean (Mucuna pruriens) on Crude Oil Impacted Soils. RA: Journal of Applied Research, 4, 1575-1580.

[18] International Organization for Standardization (1995) ISO 11466: Soil Quality-Extraction of Trace Elements Soluble in Aqua Regia.

https://www.iso.org/standard/19418.html

[19] International Organization for Standardization (1993) ISO NF X31-151: Soil Quality. Soils, Sediments, Sewage Plant Sludges. Solubilizing of Metallic Trace Elements (Cd, $\mathrm{Co}, \mathrm{Cr}, \mathrm{Mn}, \mathrm{Ni}, \mathrm{Pb}, \mathrm{Zn}$ ) by Acid Attacks.

https://arenatecnica.com/en/technical standards/nf_x31-151

[20] Ghosh, M. and Singh, S.P. (2005) A Comparative Study of Cadmium Phytoextraction by Accumulator and Weed Species. Environnment Pollution, 133, 365-371. https://doi.org/10.1016/j.envpol.2004.05.015

[21] Marchiol, L., Assolari, S., Sacco, P. and Zerbi, G. (2004) Phytoextraction of Heavymetals by Canola (Brassica napus) and Radish (Raphanus sativus) Grown on Multicontaminated Soil. Environmental Pollution, 132, 21-27.

https://doi.org/10.1016/j.envpol.2004.04.001

[22] Waranusantigul, P., Kruatrachue, M., Pokethitiyook, P. and Auesukaree, C. (2008) Evaluation of $\mathrm{Pb}$ Phytoremediation Potential in Buddleja asiatica and B. paniculata. Water, Air and Soil Pollution, 193, 79-90.

https://doi.org/10.1007/s11270-008-9669-0

[23] Olatunji, O., Ximba, B. J., Fatoki, O. S. and Opeolu, B. O. (2014) Assessment of Phytoremediation Potential of Panicum maximum (Guinea Grass) for Selected Heavy Metal Removal from Contaminated Soils. African Journal of Biotechnology, 13, 1979-1984. https://doi.org/10.5897/AJB2014.13635

[24] Gerendás, J., Polacco, J.C., Freyermuth, S.K. and Sattelmacher, B. (1999) Significance of Nickel for Plant Growth and Metabolism. Journal of Plant Nutrition and Soil Sciences, 162, 241-256. https://doi.org/10.1002/(SICI)1522-2624(199906)162:3\%3C241::AID-JPLN241\%3E3 .0.CO;2-Q

[25] Olowoyo, J.O., Mugivhisa, L.L. and Busa, N.G. (2015) Trace Metals in Soil and Plants around a Cement Factory in Pretoria, South Africa. Polish Journal of Environmental Studies, 24, 2087-2093. https://doi.org/10.15244/pjoes/43497

[26] Onojake, M.C. and Enukoha, N.N. (2018) Bioconcentration of Some Trace Metals in Panicum maximum and Colocaesia esculenta from Two Automobile Workshops 
in Choba and Alakahia, Obio-Akpor Local Government Area, Rivers State, Nigeria. Scientia Africana, 17, 1118-1931.

[27] Verbruggen, N., Hermans, C. and Schat, H. (2009) Molecular Mechanisms of Metal Hyperaccumulation in Plants. New Phytologist, 181, 759-776.

https://doi.org/10.1111/j.1469-8137.2008.02748.x

[28] Cecchi, L., Gabbrielli, R., Arnetoli, M., Gonnelli, C., Hasko, A. and Selvi, F. (2010) Evolutionary Lineages of Nickel Hyperaccumulation and Systematics in European Alysseae (Brassicaceae): Evidence from nrDNA Sequence Data. Annals of Botany, 106, 751-767. https://doi.org/10.1093/aob/mcq162

[29] Krämer, U. (2010) Metal Hyperaccumulation in Plants. Annual Review of Plant Biology, 61, 517-534. https://doi.org/10.1146/annurev-arplant-042809-112156

[30] Haydon, M.J. and Cobbett, C.S. (2007) Transporters of Ligands for Essential Metal Ions in Plants. New Phytologist, 174, 499-506. https://doi.org/10.1111/j.1469-8137.2007.02051.x

[31] Montargès-Pelletier, E., Chardot, V., Echevarria, G., Michot L.J., Bauer, A. and Morel, J.L. (2008) Identification of Nickel Chelators in Three Hyperaccumulating Plants: An X-Ray Spectroscopic Study. Phytochemistry, 69, 1695-1709.

https://doi.org/10.1016/j.phytochem.2008.02.009

[32] Araujo, G.C.L., Lemos, S.G. and Nabais, C. (2009) Nickel Sorption Capacity of Ground Xylem of Quercus Ilex Trees and Effects of Selected Ligands Present in the Xylem Sap. Journal Plant Physiology, 166, 270-277.

https://doi.org/10.1016/j.jplph.2008.06.001

[33] Alves, S., Nabais, C., Simões-Gonçalves, M.D.L. and Correia-dos-Santos, M.M. (2011) Nickel Speciation in the Xylem Sap of the Hyperaccumulator Alyssum serpyllifolium ssp. Lusitanicum Growing on Serpentine Soils of Northeast Portugal. Journal of Plant Physiology, 168, 1715-1722. https://doi.org/10.1016/j.jplph.2011.04.004

[34] CEAEQ (Centre d'expertise en analyse environnementale du Québec) (2016) Détermination de la demande chimique en oxygène: méthode de reflux en système fermé suivi d'un dosage par colorimétrie avec le bichromate de potassium, M.A.315-DCO 1.1, Revision 4. Centre d'expertise en analyse environnementale du Québec, Québec.

[35] Arbona, V., Lopez-Climent, M.F., Perez-Clemente, R.M. and Gomez-Cadenas, A. (2009) Maintenance of a High Photosynthetic Performance Is Linked to Flooding Tolerance in Citrus. Environmental and Experimental Botany, 66, 135-142. https://doi.org/10.1016/j.envexpbot.2008.12.011

[36] Bai, T., Li, C., Li, C., Liang, D. and Ma, F (2013) Contrasting Hypoxiatolerance and Adaptation in Malus Species Is Linked to Differences in Stomatal Behavior and Photosynthesis. Physiologia Plantarum, 147, 514-523.

https://doi.org/10.1111/j.1399-3054.2012.01683.x

[37] Pascault, N. (2010) Response of Soil Microbial Communities to the Supply of Crop Residues: Influence of Agricultural Practices and Link to the Biological Functioning of the Soil. PhD Thesis, University of Bourgogne, Bourgogne.

[38] Patra, M., Bhomik., N, Bandopadhyay, B. and Sharma, A. (2004) Comparison of Mercury, Lead and Arsenic with Respect to Genotoxic Effects on Plant Systems and the Development of Genetic Tolerance. Environmental and Experimental Botany, 52, 199-223. https://doi.org/10.1016/j.envexpbot.2004.02.009

[39] Seregin, I.V., Shpigun, L.K. and Ivanov, V.B. (2004) Distribution and Toxic Effects of Cadmium and Lead on Maize Roots. Russian Journal of Plant Physiology, 51, 
525-533. https://doi.org/10.1023/B:RUPP.0000035747.42399.84

[40] Larkum, A.W.D., Drew, E.A. and Ralph, P.J. (2006) Photosynthesis and Metabolism in Seagrasses at the Cellular Level. In: Larkum, A.W.D., Orth, R.J. and Duarte, C.M., Eds., Seagrasses. Biology, Ecology, and Conservation, Springer, Dordrecht, 323-345.

[41] Chen, C., Huang, D. and Liu, J. (2009) Functions and Toxicity of Nickel in Plants: Recent Advances and Future Prospects. CLEAN: Soil, Air, Water, 37, 304-313. https://doi.org/10.1002/clen.200800199

[42] Mendoza-Cózatl, D.G., Butko, E., Springer, F., Torpey, J.W., Komives, E.A., Kehr J. and Schroeder, J.I. (2008) Identification of High Levels of Phytochelatins, Glutathione and Cadmium in the Phloem Sap of Brassica napus. A Role for Thiol-Peptides in the Long-Distance Transport of Cadmium and the Effect of Cadmium on Iron Translocation. Plant Journal, 54, 249-259.

https://doi.org/10.1111/j.1365-313X.2008.03410.x

[43] Gong, J.M., Lee, D.A. and Schroeder, J.I. (2003) Long-Distance Root-to-Shoot Transport of Phytochelatins and Cadmium in Arabidopsis. Proceedings of the National Academy of Sciences of the United States of America, 100, 10118-10123. https://doi.org/10.1073/pnas.1734072100

[44] Page, V. and Feller, U. (2005) Selective Transport of Zinc, Manganese, Nickel, Cobalt and Cadmium in the Root System and Transfer to the Leaves in Young Wheat. Annals of Botany, 96, 425-434. https://doi.org/10.1093/aob/mci189

[45] Mesjasz-Przybylowicz, J., Przybylowicz, W.J., Barnabas, A. and Van Der Ent, A. (2016) Extreme Nickel Hyperaccumulation in the Vascular Tracts of the Tree Phyllanthus balgooyi from Borneo. New Phytologist, 209, 1513-1526.

https://doi.org/10.1111/nph.13712 